\title{
When anxious mothers meet social media: WeChat, motherhood and the imaginary of the Good Life
}

\author{
Bingchun Meng \\ Department of Media and Communications, LSE
}

\begin{abstract}
:
In this article I have tried to unpack the anxiety of Chinese middle-class mothers through examining the dialectics of structural changes and discursive shifts. The theoretical premises are that, on the one hand, China's highly compressed modernization process has had a major impact on parenting arrangements and parenting ethos; on the other hand, the practice of mothering and the imaginary of motherhood have significant implications for social reproduction. Combining empirical materials collected through a social media platform, in-depth interviews and focus groups, I have teased out the classed imaginaries of good mothering and how these are subsequently linked to imaginaries of the good life.
\end{abstract}


Anxious is the best word to describe the mind-set of Chinese middle-class mothers. Even before her child is born, the expectant mother starts weighing the different options for childcare and her career path after giving birth. As soon as the baby arrives, the anxiety intensifies over endless choices to be made with regard to childrearing and early education. The famous Chinese saying "don't let your child lose at the starting line" perfectly captures the intense competition which now starts earlier and earlier, placing enormous pressure on mothers. This anxiety betrays both a sense of urgency in the present and a feeling of uncertainty about the future. On social media, in the popular press and amidst the deluge of commercial advertising, mothers are constantly exhorted to do the right thing now in order to maximize their children's life chances later on.

This phenomenon is not in itself unique to China. That mothers assume primary responsibility for the physical, emotional and intellectual wellbeing of children - what Hays (1996) characterizes as "intensive mothering" - is well recognized among middle-class families in many different countries. But how has such anxiety grown in the context of the broader sociocultural transformation of recent decades in China? How is it articulated with other affective responses to societal changes to formulate the "structure of feeling" of Chinese middle-class parents? And how are the discursive formations concerning motherhood and the good life produced and circulated with the help of new technologies and communication platforms? These are the questions I aim to address in this article.

I first discuss here the privatization of education and the increasingly unequal distribution of educational resources. These structural changes have not only shifted the burden of childrearing from the collective (in the form of public provision of schooling) to individual families, which now have to purchase educational products on the commercial market, but also fostered a consumerist ideology of parenting. I then zoom in to unpack the middle-class articulation of good mothering by focusing on discourses of both the aspirational and the abject. The former refers to the imaginary of the good life (Berlant 2011) and what mothers need to do in order to bring this about for their children, while the latter contains a deep-seated fear and 
resentment of the Other from whom middle-class mothers wish to distance their children (Skeggs 1997; Walkerdine, Lucey, and Melody 2001).

The empirical materials for this study came primarily from two sources: a thematic and discourse analysis of parenting advice offered by WeChat Public Accounts, ${ }^{1}$ and in-depth interviews with both middle-class and working-class mothers. My initial intention of including working-class mothers was in order to highlight how inequality is manifested in motherhood and to gauge the extent to which working-class parenting equates to the imagined Other of the middle class. But something unexpected emerged during my research. Because working-class mothers have much less exposure to social media content and less resources for following the parenting advice geared to well-to-do demographics, they turned out to be less anxious than their middle-class counterparts and to have more realistic expectations about what a good life for their children could be. But this is not a full-fledged comparative study for two important reasons. The working-class interviewees included here are all peasant migrant workers currently living in Shanghai. While their experiences do shed light on the classed nature of mothering practice and ethos, the subordinate classes in contemporary China are comprised of much more diverse groups that also include urban public sector workers and peasants whose value system and lifestyle may well differ from migrant workers. Secondly, the research question about WeChat mediated motherhood is premised upon the assumption of an urban middle-class lifestyle.

Rather than a comparison on equal footing that inquires into working class motherhood from their own vantage point, interviews of migrant workers primarily serve as reference points for highlighting the key features of middle-class motherhood.

\section{The affective life of neoliberalism}

Much has been written about the affective life of neoliberalism as a central mechanism for producing desires, attachments and aspirations, all of which ultimately contribute to the construction of a neoliberal subjectivity that both absorbs and reacts to political and economic transformation at the structural level (Anderson 2012; 2016; Berlant 2011; Hall and O'Shea 2013; Dean 2008; Gill and Kanai 2018). The retreat of

\footnotetext{
${ }^{1}$ The Public Account is a hugely popular feature of WeChat that allows individuals and small businesses to set up their own channel for content distribution. These subscription-based accounts provide a large variety of content.
} 
the welfare state, the ascendance of market fundamentalism, and the privatization of public services in Anglo-American contexts all have consequences for the psyche of individuals living through these changes. Crucially to the focus of this study, these influences are highly mediated, through representations of a good and desirable life, narratives of success and failure, and popular discourses concerning technologies of the self. A neoliberal subject is expected to take full responsibility for their own wellbeing and to constantly make the right choices in order to gain the upper hand in cut-throat competition. Unsurprisingly, this imperative of making a competitive choice at every turn in life "has been paralleled by an upsurge in feelings of insecurity, anxiety, stress and depression" (Hall and O'Shea 2013, 12). Isin (2004) argues that these feelings constitute a further subject that the calculating, responsible and rational subject is predicated upon and accompanied by: the neurotic subject. The neurotic subject demands the impossible. It articulates neurotic claims to "security, safety, body, health, wealth, and happiness as well as tranquillity, serenity and calm." But since the neurotic subject has always been promised the impossible, it lacks the capacity to address its own illusion (232). This is why Berlant maintains that aspirations to a good life under a neoliberal regime can function as a cruel optimism at times "when the object that draws your attachment actively impedes the aim that brought you to it initially" (Berlant 2011, 1). Cruel optimism is an incitement to inhabit an affective attachment to fantasies of a "good life" which become increasingly fantasmatic, or even lead, for many, to a bad life which wears out the subjects (27). The instability, fragility and high cost of good-life fantasies are an index of the crisis of state participation in the economic and social life of a population.

Although Isin's summary of such "neurotic claims" and Berlant's discussion of good-life fantasies are reminiscent of the kind of expectations that middle-class Chinese mothers often have for their children's lives, I want to note that in China neoliberalism is still largely an exception, in both senses of that term discussed by Ong (2006). First, compared with the UK or the US, the Chinese state is far more interventionist in dealing with global capital and redressing the social inequality resulting from capitalist developments. The legacy of patriarchal statism and socialism lingers and is often evoked by both the Chinese Communist Party and the disenfranchised population when articulating a necessity to curb the power of capital 
(Nonini 2008). At the same time, the Party-state is pushing increasingly for privatization in many areas, including previously key sites of the socialist welfare system such as housing, childcare and education. In this regard, "neoliberalism is not the general characteristics of the technologies of governing" (Ong 2006, 4). In certain sectors, however, and in the more developed regions of the country where marketdriven calculation has been introduced, neoliberal rationality is gradually taking hold and promoting individualization and self-responsibilization as the drivers for achieving a good life. Secondly, the unevenness of neoliberalization, coupled with the existing social inequality in China, means that some populations have encountered and internalized neoliberal logic more than others. Elsewhere I have examined how middle-class mothers in Shanghai are frequently interpellated by advertisements in urban public space to act as savvy, responsible consumers who make the right decisions to maximize the welfare of the family (Orgad and Meng 2017). The exponential growth of $\mathrm{WeChat}$ in recent years as part of the daily information infrastructure of urban life has created a new space for the production and circulation of discourses that articulate the "common senses" (Hall and O'Shea 2013) of mothering and motherhood. But this "common sense" has a distinctly class dimension and is particularly oriented towards urban middle-class mothers.

\section{The anxious mother in post-Mao China}

In order to understand how the anxiety of Chinese urban middle-class mothers has been building in response to broad structural changes, there needs to be discussion of two important issues, namely the privatization of education and the growing class tensions as Chinese society moves from a fairly egalitarian to a highly stratified one. Both these changes, however, are predicated on the transformation of family structures and on a gendered division of labor within families.

Four decades of rapid economic development and urbanization have significantly reconfigured family life in China. Earlier research on the Chinese family shared the consensus that the modernization process had resulted in a decline in parental authority, an increase in youth autonomy and a deterioration in filial piety. More recently, scholars have pointed out that relinquishing an unconditional expectation of obedience by one's junior has paved the way for intergenerational intimacy within families, many of which have now shifted their focus of existential meaning from 
ancestors to grandchildren. This is what Yan (2016) calls the rise of descending familism in rural China. In urban areas, the implementation of the one-child policy only intensified the concentration of family resources, attention and affection on grandchildren. There is no doubt that children in contemporary China are both the love objects and the education project of the whole family (Liu 2015), to such an extent that Chinese singletons (only children) of both genders and of differing aptitude and socioeconomic statuses are all "raised with the kind of heavy parental investment, high expectations, consumption demands, and educational aspirations common among children of highly educated professionals in developed countries" (Fong 2011, 2). Ethnographic research conducted by Kipnis (2011) in Zouping, a county-town in Shandong province, seems to corroborate the findings from Fong's study of Chinese singletons studying overseas. Even in a small city far from the metropolis, Kipnis was able to discern an intensification of what he calls "educational desire" as a result of the one-child policy.

Although this educational desire is shared by the whole family, decisions about how best to fulfill it rest predominantly with the mother. Just as in many other cultures, mothers are not only the default caretakers (Chodorow 1999), but more importantly assume primary responsibility for the physical, emotional and intellectual wellbeing of children (Hays 1996). In pop-psychology books and in media reports, we find a plethora of stories that attribute all sorts of issues in adult life to the mother's negligence during childhood. The exhortation to good mothering in the private sphere coincides with the withdrawal of the state from ensuring gender equality in the public realm. While the socialist revolution made a significant contribution to gender equality in China (Croll 1978; Wang 2016), the call for women to "hold up half the sky" by joining the workforce was never accompanied by any measures encouraging men to share more household responsibilities such as childrearing. In the post-Mao era, the gendered division of labor is only reinforced by the changing pattern of work and employment. Since the start of economic reform, the Chinese state's retreat from the provision of equal employment opportunities and social care have put women in a precarious position on the labor market. With the work unit taking over the hiring process, women are often blatantly discriminated against on the grounds that they carry too great a burden of housework and childrearing responsibilities (Honig and Hershatter 1988). The restructuring of State-Owned Enterprises (SOEs) also means 
that women have been more likely than men to be laid off and have had difficulty reentering the labor market (Meng and Huang 2017). Further, with the expansion of the middle class and the ascendance of consumerist ideology, Chinese urban middle-class mothers are constantly interpellated to act as "consumers-in-chief" for their families, especially in making good purchasing decisions for their children (Meng and Huang 2017; Orgad and Meng 2017). The responsibility of motherhood is fulfilled by practicing the right kind of consumption in relation to childrearing.

As the privatization of childcare and the marketization of education at every level expand in post-Mao China, a good mother's consumption practices certainly go beyond securing the physical wellbeing of her children. According to a Chinese Academy of Social Sciences report, 70\% of Beijing parents aged between 35 and 44 said the only purpose of their family savings was to pay for their children's education, and about $60 \%$ of Chinese families in major cities now spent one-third of their monthly income on this (Xinhua 2007). More recent research by global consulting firms (Goldman Sachs 2015; ICEF 2016) continues to underline urban middle-class parents' willingness to invest in their children's education, while less data is available on the educational spending of working-class parents. In a commercial environment, demand and supply are mutually constitutive. On the one hand, increasing parental investment and consumption demands in relation to children's education has given rise to the exponential growth of a wide range of educational services and products catering to families with differing purchasing power (Chan and Wang 2009; Mok 1997; 2005). On the other hand, private companies are ingenious not only in identifying business opportunities in anything child-rearing-related, but also in devising marketing rhetoric that preys on the anxiety of parents. Social media in particular have become a channel conducive to disseminating the commercial discourses that I examine more closely in the next section.

Needless to say, the privatization of educational services and the commodification of educational products intersect with the existing class structure on multiple levels. Similarly to Bourdieu's critique of the social distinction of taste, the imaginary of good mothering and a good life correlates not only with economic capital for purchasing, but also with social and cultural capital for negotiating meaning. Ehrenreich (1989) attributes the perennial "fear of falling" of the professional middle 
class to their perception of the socio-economic structure. She points out that the creation of "professionals" as a category was designed as much to keep people out as to let them in. Unlike the truly wealthy, who are sure that their children will also be wealthy, the professional middle class now worry that their children may not be able to gain admission to the club they themselves are in. Middle-class parents have discovered that the barriers erected to exclude the lower classes from moving up could also be placed in the way of middle-class youth, and this discovery has led to a "pervasive and deep-seated anxiety." Compared with the American middle class that Ehrenreich discusses in her book, however, the emergent Chinese middle class has a different set of reference points when it comes to imagining the good life (Berlant 2011). For the former group, antithetical imaginaries are represented by the counterculture movement of the 1960s and the neoconservatives who co-opted the American working class by purporting to represent traditional American values. For the latter, bringing about a good life for their children means, for one thing, rejecting the socialist past, which epitomises deprivation and backwardness, and, for another, distancing themselves as much as possible from the contemporary working class the low suzhi (quality) population that stands no chance of winning out in the fierce competition of global capitalism (Anagnost 2014). In the next section, I use WeChat as the key discursive site for observing the classed imaginary of good mothering and the good life.

\section{The classed imaginary of the good life}

Much has been said about the huge popularity of WeChat, and previously I have examined its particular relevance for parents (Meng 2018, 159-62). Three functionalities are worth mentioning. The Moment function allows users to post messages and photos that are visible to everyone on their contact list. Mothers, especially urban middle-class mothers, often share information about children's activities via this platform. The Group function is the preferred channel for parents to exchange information about school life, to communicate with teachers, to arrange play dates and small-group activities, and to discuss any topic having to do with child rearing. The third and most important feature is WeChat's Public Account (also referred to as "official account") function, which allows individuals and private companies as well as government agencies to set up their own channel for content distribution. Small and medium-sized businesses are especially keen to invest in 
Public Accounts for marketing and promotional purposes. Data from Tencent, ${ }^{2}$ the company that developed WeChat, shows that there were 17 million active Public Accounts as of late 2017.

The sheer volume of data and the speed at which new content is generated create great difficulty in sampling when it comes to mapping the discursive landscape of any given topic online. My strategy in this study was to combine long-term online observation with recommendations from interviewees, so as to first establish a basic understanding of some of the broad topic areas and then to identify a small sample of 10 popular WeChat parenting Public Accounts for more in-depth analysis. Generally speaking, parenting-related public accounts offer a wide variety of specialized content, from child development to study-abroad agencies, from online English courses to liberal arts education. Some of these are on the WeChat channel for existing businesses, while others are first set up as interest groups, but soon find a way to cash in on the social capital of key opinion leaders (KOL). Broadly speaking, there are two types of content offered by WeChat parenting accounts: advice and advertising. The distinction between these is often blurred. For example, shortly after the wedding of Prince Harry and Meghan Markle, one of the Public Accounts targeting uppermiddle-class parents and especially those aiming to send their children to study abroad at the first opportunity published an article entitled "How to get your child invited to the next Royal wedding?". After speculating on which school the newlywed couple were likely to send their children to, the article talks at length about the kind of "aristocratic" education that elite private schools in the UK can offer. It emphasizes that this is not just about getting the right kind of education, but more importantly about getting to know the right kind of people so that your child will have an elite social circle. The article goes on to promotes Battersea in South-west London as a particularly desirable area to live in for its proximity to several private schools that "will increase your child's chance to become a guest at the next Royal wedding". Only at this point do we realise that the whole piece is an elaborate advertisement for high-end real estate.

Parenting advice can be further categorized into: health advice, which mainly caters to

${ }^{2}$ https://www.businessofapps.com/data/wechat-statistics/ 
parents of younger children; psychological advice that attends to the emotional wellbeing of both parents and children; and educational advice for improving the academic performance of school-age children. Advertisements are for both goods and services ostensibly to improve every possible aspect of children's lives and are mostly in "soft" forms, embedded in advisory content. Just like family-themed advertisements in urban public spaces, this content on WeChat Public Accounts reflects a neoliberal orientation that foregrounds self-responsibility and market exchange (Orgad and Meng 2017). Below I use two examples to illustrate middleclass mothers' imaginary of the aspirational and the abject in the future lives of their children.

The first is a Public Account with over 100,000 subscribers called YouthMBA, which was able to quickly build a large base of followers by appealing to middle-class parents' dissatisfaction with Chinese school education as well as to their admiration for so-called "Western-style" (mainly American) liberal education. The connotations of suzhi (quality) in the Chinese context is a complicated topic in itself (Anagnost 2004; Kipnis 2007; H. Yan 2003; Sun 2009). When it comes to the perception of suzhi jiaoyu (quality education), however, the Chinese middle-class would certainly rank critical thinking and creative problem-solving, which are considered key qualities (suzhi) for ensuring success in global competition, above rote learning and standardized skills, which are a trademark of conventional Chinese education. Incessantly fuelling middle-class parents' anxiety about their children's sushi, as well as their adulation of Western education, private businesses such as YouthMBA promise to make up for everything lacking in regular Chinese schools through a variety of commercial products and services. A large proportion of the educational content distributed through this channel is about English language learning, reading children's books by foreign authors and honing analytical writing skills. Online courses are offered to both parents and children on a pay-per-access basis, and phrases like "Ivy-League-trained teacher" and "Anglo-American elite school teaching materials" are the most common tag lines. YouthMBA brands itself as a "mobile international school" that brings to Chinese students "the best suzhi education curriculum around the globe." Even for non-academic content, the "West" is always the gold standard, as reflected in headlines like "Happy Schooling in Nordic Countries," "Why American School is the Best Choice for Sporty Kids," "What's so 
Damaging about Chinese-Style Negativity," or "This is how American High Schools Foster Leadership," to pick just a few.

The desire to achieve an elite bourgeois lifestyle fosters an implicit fear and resentment toward the undeserving Other. As middle-class parents invest time and money to build up the human capital of their children for future competition, they also fiercely guard their resources and privileges against what they consider the abject. Feminist scholars, especially those who focus on the intersection of gender and class, have used Kristeva's (1982) term "abject” to explore how bourgeois feminine characteristics are normalized through a "pathologization of the working class and particularly working class women and mothers as threats to the moral order who must be monitored, controlled, and reformed" (Ringrose and Walkerdine 2008, 233). In May 2017, an article entitled "Class Conflict in a Chengdu Neighborhood" (https://www.zhihu.com/question/59753079) was reposted by many Public Accounts on parenting and provoked heated discussion on Chinese social media for days. A property owner living in an upper-scale apartment complex in Chengdu, a metropolis in South-west China, posted an open letter online addressing fellow parents in the neighborhood. The letter called for solidarity among property owners in the three neighboring complexes to protest against the redrawing by the local educational authority of the catchment area for a high-performing primary school. Ostensibly the new catchment area would result in children from "lower-end" apartment complexes being admitted to a school "they don't really belong to." The letter asserted that the income level of parents "living in those areas does not match the level of education that Wang Jiang School provides." It went on to list the kinds of expenses "our kind of family" pays for "improving the suzhi of our children", such as annual study trips abroad and tutoring session on traditional culture and etiquette. "The social reality is that both suzhi and academic performance are cultivated with money (用钱堆出来的). One penny in exchange for one mark, one penny in exchange for one bit of suzhi (一 分钱一分成绩, 一分钱一分素质). Even if you are yourself well-educated, the suzhi of your children will not necessarily be higher than those of migrant workers, unless you can earn more money. My wife is a stay-at-home mom, and this is the case of many other families in our neighborhood. This allows us to provide the best care and the most well-rounded education for our kids. And we also hire tutors to have 
one-on-one sessions. Of course we bring up children with the highest suzhi possible." The letter ended by pledging, on the one hand, parents in the same neighborhood to get together more often "like a family," while dissuading those from the lowerincome neighborhood from "striving for the life the doesn't belong to them." The staggering classism of the letter certainly drew wide criticism on social media, but it was a manifestation of middle-class fear of and anxiety about the abject. In fact many people also commented that, although the expression was a bit extreme, it revealed the "harsh truth" about childrearing in urban China nowadays.

\section{Striving to be a good mother}

It was from this social context and discursive environment that I started carrying out interviews with mothers of school-age children. During two research trips in 2017, I conducted in-depth interviews and focus groups with 16 middle-class mothers and 12 working-class mothers in Shanghai found through snowball sampling. This clear imbalance between the two groups indicates a bias of access due to the researcher's own socio-economic status. Four of the middle-class mothers did not work outside the home, one was self-employed and yet another had flexible employment conditions and worked from home most of the time. Six of the working-class mothers were waitresses in a mid-range restaurant in the South-west suburbs of Shanghai, three worked in a beauty parlor, and the rest were domestic cleaners without stable employment contracts. On the basis of a combination of thematic and discourse analysis, I here compare and contrast the material provided, as well as the symbolic resources of the two groups along two dimensions, namely, imaginaries of good mothering and of a good life.

All the working-class mothers I talked to were migrant workers in the city who did not have Shanghai hukou. This lack of residential status in the city created a significant challenge for the schooling of their children. The policy is such that either children go back to their hometown, where their hukou is registered to attend public school there or parents have to pay for them to go to a private (minban) school in Shanghai. In recent years Shanghai has made efforts to open up the city's education system to migrant workers by asking only for a certificate of residence (juzhu zheng) to qualify for a place in public school. But most migrant workers do not own an apartment in the city and would need to ask their landlord for a copy of the property 
deed in order to get the juzhu zheng. All my working-class interviewees agreed that this was "a too troublesome process." More importantly, even if children can receive primary and secondary education in Shanghai, they still have to return to their hometown to take the college entrance exam (gaokao). There was a general consensus among mothers that children who had been schooled in Shanghai would not be able to compete with "kids back home" in the gaokao. As a result, only two out of the 12 working-class mothers had their children living with them in Shanghai. The rest had chosen to leave their children behind in the care of grandparents in the rural hometown.

By contrast, not only were a quarter of my middle-class interviewees stay-at-home mothers, but if some of these did need help from grandparents it was always the grandparents who came to live with them. For example, Xiaomei, who has a Master's degree from a US Ivy League university and works at a start-up she co-founded in Shanghai, told me that her parents commuted from Hangzhou every week to help take care of her five-year-old daughter.

We find this to be the best arrangement. Nowadays it's only an hour on the high-speed train from Hangzhou to Shanghai. It's like they come to work every Monday morning and go back home on Friday afternoon. It's also good for my daughter's upbringing. It's my home; they are aware I am in charge. I tell them what to do and what not to do with my daughter. If I leave her in Hangzhou with my parents, they will definitely spoil her. They just adore her so much. (March 28, 2017)

During my focus-group discussion with restaurant workers, the mothers all shared their frustration, sometimes bordering on anguish, with not being able to live with their children and raise them in the way they wanted. As if corroborating Xiaomei's view from an opposite position, Puyan recounted her recent trip back home shortly after the Chinese New Year:

So my younger one was being naughty. I forgot what it was, maybe it had to do with my husband telling him not to be glued to his phone all the time. My son got upset and threw the phone at my husband. I 
slapped him. Then my mother-in-law started crying. She said something like, 'oh you don't pamper him because you are not the one who brought him up. Slapping him is just like hitting me.' [sigh]... the elderly... what can you do? (March 29, 2017)

At this point, fellow worker Junjun chimed in, "two more years to earn a bit more money, then I will go back. I cannot stand this anymore! My daughter cried again last time I left home.” This comment, however, was met with sympathetic but disbelieving laughter from the rest of the group. Aiqin, the oldest among them and the only one who had brought her daughter to Shanghai, retorted, "I said exactly the same thing years ago! I thought I'd work here for three years, pay off the family debt, then go back. But we wanted to buy an apartment in the township after clearing our debt. So I stayed for another year, then another year, and finally I decided to bring my daughter here as I don't see myself going back soon."

Existing sociological literature makes a distinction between "intensive mothering" and "extensive mothering," with the former being typically associated with middleclass motherhood (Hays 1996) and the latter being the script adopted by workingclass or working mothers (Christopher 2012; Lavee and Benjamin 2015). The time and resource commitment for performing intensive mothering is usually unattainable for working-class families. For working mothers who are juggling several timeconsuming responsibilities, including childcare at home, school involvement and labor-market participation, it is impossible to always remain attentive to the child's needs and desires.

Xiaomei and all the other middle-class mothers I talked to performed intensive mothering to varying degrees, depending on the family situation and their own employment status. But they did not shy away from extensive mothering either, which for childcare often meant the involvement of grandparents or hiring a domestic helper, and for education finding reputable tutorial provision as well as extracurricular activities. For Puyan and her co-workers, however, delegating childrearing to grandparents was a matter of having no other options. Instead of feeling "in charge," they felt powerless, but tried to convince themselves that this was only a temporary arrangement. If something went amiss under these circumstances, though, they 
blamed themselves for not being good enough mothers.

Lareau (2003) maintains that the family-school relationship is a key factor that sets apart the achievement of middle- and upper-middle-class children from that of the working class. The contrast between separation and interconnectedness in terms of parents' school involvement was also manifest in this study, epitomizing class difference in the command of both material and symbolic resources. Chen'An was a stay-at-home mother whose teenage daughter went to an elite international school. She did a lot of volunteer work at the school, helping with school trips, Christmas fairs, end-of-year parties and so on. As we went on to talk about the educational provision at international schools and the destination of students after graduation, Chen'An started asking me for advice on studying abroad, including detailed questions comparing different overseas universities. It often happened during my interviews with middle-class mothers that they would suddenly turn the conversation around and consider me a useful source of information. But never once did this occur when I was talking to working-class mothers. They never took any interest in my job because it was too remote from their lives.

While almost all the middle-class mothers could offer not only fairly detailed accounts of their children's school lives but also critical comments on the teaching provision, including the learning materials, the amount of homework, the frequency of tests, etc., the working-class mothers in general only had a very vague idea of what their children did at school and what they needed to do after returning home in order to keep up with the coursework. For migrant mothers who had to leave their children behind, there was obviously the challenge presented by physical distance. Changmei tried to call home at least twice a week to check on her 11-year-old daughter. She stayed in touch with the teachers via a parents' group on WeChat and often needed to rely on the teacher's instructions to her in-laws, who were barely literate.

It is really hard even just finding the time to call. This is not my only job. I have another part-time job somewhere else... Many of us here do two to three jobs now. So by the time I return to the dorm, I barely have the strength to speak, let along calling home to check on my daughter's schoolwork. (March 29, 2017) 
But it is not just the physical distance that stalls parental supervision. Caiyun worked in Shanghai as a domestic cleaner and had accumulated enough points on her juzhu zheng to allow her younger son to attend a public school in the city. Having only completed primary education herself, Caiyun gave terse answers to most of my questions about her son's education. The one thing she talked at length about, though, was how worried she was about him spending too much time on his phone.

He says he needs the phone in order to do his English homework, but sometimes he spent so much time on it and by the time we got back late in the evening, he still hadn't finished his homework. I don't know what's going on! I think he chats with his friends on the phone. I wish he could spend more time studying. (December 21, 2017)

Compare this sense of helplessness with the firm attitude of Xuelian, who ran an early education center in a gated upper-middle-class neighborhood and had a daughter of similar age to Caiyun's son.

I am quite strict with my daughter. I told her from day one when we bought her a smart phone: 'this phone is for you to use, but it belongs to Daddy and Mommy. So we could take it back at any point. We set rules for you and if you violate the rules, I am afraid you will be penalized.' Now she goes to a boarding school and only has access to her phone over the weekend. So that's also good. (March 31, 2017)

Not only do middle-class mothers have a greater capacity to discipline the children, they also have the material means as well as the cultural capital to practice what Laureau calls concerted cultivation. Yejie's daughter went to a very good private middle school (minban chuzhong) after taking a competitive entrance exam. I met with her while she was waiting for her daughter to finish a Saturday English lesson, before she took her to a math tutorial in the afternoon. When I commented on the packed schedule, she looked at me earnestly: "this is normal. You have to start investing early on if you want your child to achieve anything. My nephew is only two and half years old, but he has nine different lessons every week in addition to 
going to the kindergarten.” (December 20, 2017).

\section{Aspiring to a good life}

One might think that, given the significant advantages that middle-class children enjoy in all aspects of their upbringing, their mothers would be more content and confident than their working-class counterparts. Yet my research seems to suggest the opposite. Exactly because middle-class mothers have the means and resources to pursue intensive parenting and concerted cultivation, they are the target audience for commercial messages selling all kinds of products and service to do with childrearing. More often than not, the parenting-related soft advertisements that saturate Chinese social media promote a "keeping up with the Joneses" mentality by stirring up the deep-seated anxiety of middle-class parents about falling behind. Qin was a marketing executive who subscribed to many parenting Public Accounts:

I know they run promotional content every now and then, but I am not put off by it. Actually, some of this is useful information. It's not just an advertising channel, you know. Choosing the right product for children can be overwhelming. At least I could refer to other parents' honest opinion. (December 18, 2017)

She showed me one of those typical hybrids of "promotional content" and "useful information" on her phone. iKids is a Shanghai-based parenting account co-founded by one of Qin's friends. It distinguishes itself as being the most "high-end, classy and upper-scale (高大上)" among its competitors and aims to “cultivate young cosmopolitan global citizens." "i Staying true to this slogan. iKids mainly shares information about fun experiences with children rather than academic content. A quick browse on Qin's phone gave me headlines such as “Top 10 list of Five Star Hotel Swimming Pools Around Shanghai," "My Most Recent Cruise Trip was Such a Revelation!" and "Best Holiday Experience in Mauritius." Often, in these review articles, discount purchases will be mentioned near the end as a "bonus (福利)" or an “Easter egg (彩蛋)” for subscribers to the account.

Middle-class mothers do sometimes find it difficult to cope. Yuan was a stay-at- 
home mother who had given up a well-paid corporate job to take care of her two daughters aged five and three. She had had to turn off the update alert of the parenting accounts she subscribed to

because it was too much. Sometimes I almost wanted to be an ostrich, just to bury my head in the sand so that I don't have to constantly make choices and make comparisons. You need to be mentally very, very strong. You need to know exactly what you want and what's best for the kids. Nowadays I mainly socialise with other stay-at-home moms. People have different views and sometimes I hear contradictory advice. It can really become too much. (March 28, 2017)

None of the working-class mothers I interviewed said they had heard of any of these popular parenting Public Accounts, even when I asked them specifically about WeChat usage in relation to parenting. Changmei's frustration, discussed in the previous section, about not being able to call her children often enough is a sentiment shared by many migrant mothers. They are so busy trying to make ends meet, sometimes holding on to more than one job, that they can barely spare any time and energy to fret about making the right kind of purchase.

Not having as much time as their middle-class counterparts to engage with social media, however, could be a blessing in disguise. For one thing, working-class mothers have much less exposure to the neoliberal discourse of parenting, which emphasizes individualization, self-responsibility and competition. Since they did not have a clear idea about what school offered or have time to read all the parenting advice about how to make up for whatever is perceived as lacking in school education, the migrant workers I talked to did not express concern over what constituted concerted cultivation in calculating the cost and benefit of each extra-curricular activity. By contrast, middle-class mothers are well-informed, but they are constantly seeking new advice in the hope of planning everything ahead as much as possible, as was reflected on multiple occasions when my interviewees treated me as their informant. Having too many bits and pieces of information from different channels and facing seemingly endless options proved to be exacerbating rather than appeasing their anxiety. In general, working-class parents have more faith in the public education system. Their 
basic attitude is that as long as their children go to a decent school they will be fine. Middle-class parents, however, think that there are always better services provided by the market. This of course is reinforced by the fact that they are the target audience of parenting Public Accounts.

Not using social media extensively also means that working-class mothers are subject to less surveillance of their parenting practice and ethos. As the quote above from my interview with Yuan suggests, part of the pressure comes from knowing what others are doing while at the same time feeling judged. Middle-class mothers often post photos or videos of their children's activities on WeChat Moments. They also engage in group discussion about parenting. Consciously or unconsciously, they are incessantly evaluating their performance of motherhood in comparison with others. This is why Yuan said they needed to be "mentally very, very strong," in order to stand the constant scrutiny from both their peers and themselves.

Intriguingly, when I asked the interviewees what they would consider a good life for their children, the two groups also tended to give different types of answers. In general, working-class mothers have much vaguer idea about the kind of schooling they want to put their children through, but have more specific expectations with regard to future career. Six out of the 12 migrant workers mentioned teaching or medical professions (some said doctor, others said nurse) as the ideal job that not only provides a stable income but also enjoys good social status. Middle-class mothers do not mention any particular career path. After all, the whole point of cultivating children' suzhi is to make sure as many options will be open to them as possible. Nonetheless, Yejie, herself a secondary-school teacher, was adamant about not letting her child choose teaching or a medical career. She thought both were "very tiring jobs that make you work so hard but don't pay very well. And none of them is even treated with respect by the people you dedicate the work to!" (December 20, 2017).

There is a more finely tuned distinction between middle-class and upper-middle-class parents in their pursuit of the good life. The former focus more on the academic side, as most still expect their children to excel in the national college entrance exam in China. Upper-middle-class mothers who send their children to international schools have decided to break away from the Chinese education system early on. They aim at 
elite overseas universities for their children and are more relaxed about what the children should do in the future to achieve a good life. For example, Xuelian said: "I want my daughter to have a career that brings beauty to her life and to the life of others," while Chen'An simply stated: "I just want her to be happy and find something she has a passion for."

\section{Conclusion}

In this article I have tried to unpack the anxiety of Chinese middle-class mothers through examining the dialectics of structural changes and discursive shifts. The theoretical premises are that, on the one hand, China's highly compressed modernization process has had a major impact on parenting arrangements and parenting ethos; on the other hand, the practice of mothering and the imaginary of motherhood have significant implications for social reproduction. Combining empirical materials collected through a social media platform, in-depth interviews and focus groups, I have teased out the classed imaginaries of good mothering and how these are subsequently linked to imaginaries of the good life. Although, compared with their working-class counterparts, middle-class mothers are in possession of advantageous material as well as symbolic resources, their state of mind is much more anxious, or even neurotic. This anxiety can be partly attributed to a "fear of falling" and a resentment of the abject; partly it has to do with the discursive environment they inhabit. In this sense, the privilege of middle-class intensifies the cruel optimism of neoliberal fantasies. This, however, does not mean that migrant worker mothers are less committed to maximizing the educational resources for their children or make less sacrifice for a better life of the family. Further research is to be done examining the cruel deals working-class parents might be facing in contemporary China. 


\section{References:}

Anagnost, Ann. 2004. "The Corporeal Politics of Quality ( Suzhi )." Public Culture 16 (2): 189-208.

Anderson, Ben. 2012. "Affect and Biopower: Towards a Politics of Life." Transactions of the Institute of British Geographers 37 (1): 28-43. https://doi.org/10.1111/j.1475-5661.2011.00441.x. . 2016. "Neoliberal Affects." Progress in Human Geography 40 (6): 734-53. https://doi.org/10.1177/0309132515613167.

Berlant, Lauren. 2011. Cruel Optimism. Durham, NC: Duke University Press.

Chan, Raymond K.H., and Ying Wang. 2009. "Controlled Decentralization: Minban Education Reform in China." Journal of Comparative Social Welfare 25 (1): 27-36. https://doi.org/10.1080/17486830802513983.

Chodorow, Nancy J. 1999. The Reproduction of Mothering: Psychoanalysis and the Sociology of Gender, Updated Edition. University of California Press.

Christopher, Karen. 2012. "Extensive Mothering Employed Mothers' Constructions of the Good Mother." Gender \& Society 26 (1): 73-96. https://doi.org/10.1177/0891243211427700.

Croll, Elisabeth. 1978. Feminism and Socialism in China. London: Routledge.

Dean, Jodi. 2008. "Enjoying Neoliberalism.” Cultural Politics 4 (1): 47-72. https://doi.org/10.2752/175174308X266398.

Fong, Vanessa. 2011. Paradise Redefined: Transnational Chinese Students and the Quest for Flexible Citizenship in the Developed World. Stanford University Press.

Gill, Rosalind, and Akane Kanai. 2018. "Mediating Neoliberal Capitalism: Affect, Subjectivity and Inequality." Journal of Communication 68 (2): 318-26. https://doi.org/10.1093/joc/jqy002.

Hall, Stuart, and Alan O'Shea. 2013. "Common-Sense Neoliberalism." Soundings, no. 55 (December): 9-25. https://doi.org/info:doi/10.3898/136266213809450194.

Hays, Sharon. 1996. The Cultural Contradictions of Motherhood. Yale University Press.

Honig, Emily, and Gail Hershatter. 1988. Personal Voices: Chinese Women in the 1980's. Stanford: Stanford University Press.

Isin, Engin F. 2004. "The Neurotic Citizen.” Citizenship Studies 8 (3): 217-35. https://doi.org/10.1080/1362102042000256970.

Kipnis, Andrew. 2007. "Neoliberalism Reified: Suzhi Discourse and Tropes of Neoliberalism in the People's Republic of China." Journal of the Royal Anthropological Institute 13 (2): 383-400. https://doi.org/10.1111/j.14679655.2007.00432.x.

Lareau, Annette. 2003. Unequal Childhoods: Class, Race and Family Life. Oakland, CA: University of California Press. https://www.ucpress.edu/book/9780520271425/unequal-childhoods.

Lavee, Einat, and Orly Benjamin. 2015. "Working-Class Mothers' School Involvement: A Class-Specific Maternal Ideal?" The Sociological Review 63 (3): 608-25. https://doi.org/10.1111/1467-954X.12253.

Liu, Fengshu. 2015. "The Rise of the 'Priceless' Child in China." Comparative Education Review 60 (1): 105-30. https://doi.org/10.1086/684457.

Meng, Bingchun. 2018. The Politics of Chinese Media:Consensus and Contestation. Palgrave Macmillan. https://www.palgrave.com/gp/book/9781137462138. 
Meng, Bingchun, and Yanning Huang. 2017. "Patriarchal Capitalism with Chinese Characteristics: Gendered Discourse of 'Double Eleven' Shopping Festival." Cultural Studies 31 (5): 659-84. https://doi.org/10.1080/09502386.2017.1328517.

Mok, Ka Ho. 1997. "Privatization or Marketization: Educational Development in Post-Mao China." International Review of Education / Internationale Zeitschrift Für Erziehungswissenschaft / Revue Internationale de l'Education 43 (5/6): 547-67. . 2005. "Riding over Socialism and Global Capitalism: Changing Education Governance and Social Policy Paradigms in Post-Mao China." Comparative Education 41 (2): 217-42.

Nonini, Donald M. 2008. "Is China Becoming Neoliberal?" Critique of Anthropology 28 (2): 145-76. https://doi.org/10.1177/0308275X08091364.

Ong, Aihwa. 2006. Neoliberalism as Exception: Mutations in Citizenship and Sovereignty. Durham, NC: Duke University Press.

Orgad, Shani, and Bingchun Meng. 2017. "The Maternal in the City: Outdoor Advertising Representations in Shanghai and London." Communication, Culture \& Critique 10 (3): 460-78. https://doi.org/10.1111/cccr.12171.

Skeggs, Beverley. 1997. Formations of Class \& Gender: Becoming Respectable. SAGE.

Sun, Wanning. 2009. "Suzhi on the Move: Body, Place, and Power." Positions 17 (3): 617-42. https://doi.org/10.1215/10679847-2009-017.

Thrift, Nigel. 2004. "Intensities of Feeling: Towards a Spatial Politics of Affect." Geografiska Annaler: Series B, Human Geography 86 (1): 57-78. https://doi.org/10.1111/j.0435-3684.2004.00154.x.

Walkerdine, Valerie. 1990. Schoolgirl Fictions. Verso Books.

Walkerdine, Valerie, Helen Lucey, and June Melody. 2001. Growing up Girl: Psycho-Social Explorations of Gender and Class. Basingstoke: Palgrave. http://orca.cf.ac.uk/3204/.

Wang, Zheng. 2016. Finding Women in the State: A Socialist Feminist Revolution in the People's Republic of China, 1949-1964. University of California Press.

Yan, Hairong. 2003. "Neoliberal Governmentality and Neohumanism: Organizing Suzhi/Value Flow through Labor Recruitment Networks." Cultural Anthropology 18 (4): 493-523. https://doi.org/10.1525/can.2003.18.4.493.

Yan, Yunxiang. 2016. "Intergenerational Intimacy and Descending Familism in Rural North China." American Anthropologist 118 (2): 244-57.

\footnotetext{
${ }^{\mathrm{i}}$ These are the words used by the founder during an interview with me to describe her aspiration.
} 